\title{
NATIONAL CULTURAL FEATURES OF THE CONCEPT "OSTONA" (ON THE EXAMPLE OF S.AHMAD'S NOVEL “UFQ”)
}

\author{
Mahmudova Sadoqat \\ Teacher of Bukhara State University
}

\begin{abstract}
To date, the problem of language and culture compatibility has attracted the attention of many scholars, linguists and researchers. Different approaches to this topic are being studied in the fields of linguistics, such as linguocultural studies, psycholinguistics, ethnolinguistics, sociolinguistics, history, and literature. Researchers have explored the relationship between language and culture, and have explored whether they are interconnected permanent units or important complementary components.

Key words: language and culture compatibility, scholars, linguists and researchers, fields of linguistics, linguocultural studies, psycholinguistics, ethnolinguistics, sociolinguistics.
\end{abstract}

\section{I.Introduction}

Cultural values are expressed in language and communicated to the public. Language is the main tool in giving. Language embodies the national landscape of the world, the identity of the people and the national culture. The relationship between language and culture is especially evident in the teaching of the Uzbek language. In addition to learning one's mother tongue, one gradually acquires one's own national culture and traditions and customs. In this process, he realizes the secular landscape of the people, the nation.

\section{II.Literature review}

The interaction of culture with language is a complex psycholinguistic process and is important. In the combination of language and culture, a person is involuntarily confronted with the terms that make up the important lexical structure of the language. Language is a tool for perceiving and knowing reality. Cognitive linguistics is the study of language as a cultural phenomenon that examines the construction of human knowledge and experience. The basic unit of cognitive linguistics is concept. Concepts are also at the heart of a number of studies on the study of the Uzbek language in the cognitive sphere. In the emerging paradigms of Uzbek linguistics, the term concept is widely used. The two-volume dictionary "Explanatory Dictionary of the Uzbek language" does not give the meaning of this word. At the time the dictionary was created, the concept was used neither scientifically nor philosophically. However, his interpretation did not appear in the new five-volume glossary. It is also not given in the "Explanatory Dictionary of Linguistic Terms" (A. Khojiev). This means that the term is not yet firmly established in Uzbek science or exists as a terminological neologism.

\section{III.Analysis}

The term concept began to appear in linguistic research in the first half of the twentieth century. The term is an English word (concept), translated into Russian as ponyatie (concept). Later, when the term was confused with the term concept, work began to be done to formulate its exact meaning. In a linguistic encyclopedic dictionary, the term concept is defined as follows: a concept is a concept like "meaning of a word" and differs only in terms of the system of connections; in the semantic-linguistic system; the concept is in a system of logical relationships and forms that is studied in both logic and linguistics."

We have stated above that in cognitive linguistics, a concept is considered a key figure. We can confirm this with the following cases:

1) mental resource units of human consciousness, human knowledge and in the cognitive field a mental unit representing an information structure that reflects experience is considered as a concept;

2) one of the main branches of cognitive linguistics is "cognitive semantics" studies the nature and structure of the concept;

3) in cognitive linguistics, mainly between concept and word meanings attitude is analyzed.

In the Concise Dictionary of Cognitive Terms, a concept is defined as a worldview reflected in the human mind, a mental lexicon, a conceptual system, and a structural operational unit of language and memory. A. Vejbiskaya gave the first definition of the concept as a linguistic concept. According to him, "a certain culturally conditioned perception of the world of 'truth', which has its own name, is defined as the object of a 'peculiar' world." Researcher Frunkina tries to divide the concept into types: "There are two different concepts in the language system. While the first type of concepts are universally meaningful (sleep, eat, start, read,) concepts, the second type includes concepts that have national-cultural value (bread, guest, parent, wedding, home, friend, homeland).

We are analyzing: "Ostona" - the concept in the form of a river threshold or threshold, which is also mentioned 
in Mahmud Kashgari's work "Devonu lug'otit turk".

"Ostona" - concept (Persian-Tajik) Door, gate, lower crossbeam of the frame; timber, planks, rocks, etc. laid across the ground at the entrance to the building, yard. Linguistically, the word threshold can be used in the context not only in its own sense, but also as a metaphor in a figurative sense. Threshold at the entrance to a village or town. When you are close to the beginning of an event or incident; in the sense of arafa.

\section{IV.Discussion}

In the linguistic and cultural foundations of the "Ostona" concept, we can see that the spirit of science, education, national culture and patriotism, which our ancestors have long considered a priceless treasure, is the key to human development and national development. In particular, it is impossible to develop a patriotic spirit in young people without changing the system of national culture and, on this basis, consciousness. When a baby is born, it is happily brought home. When he reaches the end of his life, he will not be taken out of the threshold. But old age is like standing on the threshold. These national cultural features testify to the long historical development of the threshold concept.

At the heart of the events described in the novel "Ufq" by the writer Said Ahmad are the themes of peace, war, courage, devotion, and the upbringing of children. The novel covers the decade of the nation's life in the 20th century World War II, the war and its aftermath. The trilogy depicts the tragedies that befell the people of those years, the aspirations of the people, the unparalleled tenacity and courage to overcome these tragedies, the passion and inspiration of the writer's talent.

He did not know that he had sent a voice to himself, saying, "The child has fallen." He crossed the threshold and went inside. The yard is quiet. Water was sprinkled everywhere. Ikram rolled the handkerchiefs on the porch and looked inside the house. The place was not packed. ... Ikram kicked on the threshold, dusted his boots, went in and put a sheet on his son's head.

The national cultural feature of the threshold concept expressed in the example: despite the difficulties of that time, Ikromjon and his wife, Aunt Jannat, work together. But disaster strikes in their lives. Tursunboy, the only son of their children, who did not believe in the land and the sky, escaped on the way to war. Entering the threshold, the life of the father, who thought of the happiness of this son, was ruined. It has been reaffirmed that the responsibility of parents in raising their children lies within that threshold.

In the case of a father stepping on the threshold and dusting his shoes, the love of a father who considers only the beauty of this world worthy of his child is expressed. The highest value in the world for a person is to have a national and cultural upbringing. In the play, we can see how much the young Uzbeks, who went to war instead of dignity, are loved and respected by their families.

In the end, the patriarch agreed with the groomsmen from Margilan. The wedding day has also been set. He crossed the threshold and did not let his sister out.

In the play, the love of Lutfinisa and Azizkhan was an ancient love that was not written in any book, did not come into the language of any poet. Lutfinisa's brother Akbarali, who did not consider this young man worthy of his sister, was worried about his sister's fate after his parents and wanted to give her to a young man from Margilan and set a wedding date. The reason why he did not let his sister out on the doorstep was that he was expecting a lot from the wedding. In this example, we can see the national cultural feature of the threshold concept in two ways: on the one hand, if the chastity, pride and honor of girls are protected by the liver; on the other hand we can see the fate of the sisters who are sacrificed for the benefit of their livers.

\section{V.Conclusion}

Although the main part of any national culture is created by that nation, it will, of course, have a share and influence of the universal culture created by the peoples of the world. In conclusion, it should be noted that the Uzbek people have not experienced many days. Here we have reached the era of peace, independence and freedom that our ancestors dreamed of.

\section{References:}

1.Safarov SH. Cognitive linguistics. -Jizzax: Sangzor, 2006. -P. 14.

2.Linvisticheskiy ensiklopedicheskiy slovar. -M .: SE, 1990.

3.Vejbiskaya A. Yazik. Culture. Recognition. -M. Russian Dictionaries, 1996.

4. Djusupov N. M. Ligvokognitivnie aspekt issledovaniya simvola xudojest- vennom tekste: Avtoref.diss... kand. filol. science.

5. Compare the data from A. Vejbiskaya's research with other sources an objective study of the subject is important in illuminating the subject under consideration became important

6. Short dictionary of cognitive terms / E.S.Kubryakova, V.Z.Demyankov, YU.G.Pankras, L.G.Luzina. -M .: 1966. 
7.S.Ahmad Ufq.- Sano-standart: Tashkent, 2019.-Pp. 6-19.

8. Azam E. Where is Paradise? - T .: "Sharq" 2007. - 272 pages.

9. Rustamova M. The method of psychological analysis in the Uzbek stories and narratives of the new period. - "Language and Literature Education", 2005, No. 2. - Pages 60-67.

10. Ruzmatova G. Freudianism: the problem of consciousness and unconsciousness. - "Tafakkur", 2007, issue 1. - pp. 8287.

11. Olimov M. The pathos of heroism. - "OTA", 2006, issue 4. Pages 52-54.

12. Abdurahmanova M. The image of the spiritual world. - T., 1977. 